\title{
Using Brain-Based Learning to Promote Students' Concept Mastery in Learning Electric Circuit
}

\author{
Aulianuriy Sani ${ }^{*}{ }^{*}$, Diana Rochintaniawati ${ }^{1}$, Nanang Winarno ${ }^{1}$ \\ ${ }^{1}$ International Program on Science Education, Faculty of Mathematics and Science Education, Universitas Pendidikan Indonesia, \\ Indonesia \\ *Corresponding Author. aulianuriy@gmail.com
}

\begin{abstract}
Teaching approaches in some school are still concentrating on memorizing. Teachers have to make the learning is meaningful for the students. One of the alternative tools is by using Brain-Based Learning. The purpose of this study is to investigate the effect of Brain-Based Learning on students' concept mastery in learning electric circuit for 8th-grade students. The method used in this research was experimental research. The research design that used is pretest and posttest design. The sample was taken by random sampling in class. Participants were 49 students at one of International Secondary School in Bandung, West Java, Indonesia. Experiment group learns with Brain-Based Learning $(\mathrm{N}=26)$ while the control group learning with lectured based learning $(\mathrm{N}=23)$. The results of students' concept mastery that learned using Brain-Based Learning is better than students' concept mastery that learned using lectured-based learning. The improvement of students' concept mastery can be noticed by independent t-test with significant 0.003 . Based on the analysis of students' concept mastery results, the $\mathrm{N}$-Gain score in experiment group is 0.43 which categorized as a medium improvement while in the control group is 0.25 which categorized as a low improvement. Based on these results showed that Brain-Based Learning can be an alternative tool to improve students' concept mastery significantly.
\end{abstract}

Keywords Brain-based learning, Students' concept mastery, Electric circuit

\section{INTRODUCTION}

Currently, technological advances in the world are growing rapidly. The instructional method in school needs to adjust with the more unpredictable learning condition instead of previously (Saleh, 2012). Aziz (in Shabatat \& AlTarawneh, 2016) stated that teaching approaches are still concentrating on memorizing. These make the students only act as a receiver of information sent by the teacher without relating to students' interest and these approaches make students' receive the information without thinking independently and processing although the students have imagination and active thinking. According to $\mathrm{Al}$ Tarawneh (2016), the educators and psychologists, refinement of teaching and learning process using the neurocognitive concept to bring up Brain-Based Learning (Shabatat \& Al-Tarawneh, 2016).

Dissimilar to conventional techniques of schooling, which is frequently said to restrain learning by overlooking the brain's regular learning forms, the Brain-Based Learning is accepted to support learning because of its allencompassing methodology towards the students. It is a way to deal with realizing which supports the brain's best common operational standards, with the goal of attaining maximum attention, understanding, meaning, and memory (Jensen, 2008).

Brain-Based Learning is a student-focused and instructor encouraged methodology that uses students' intellectual gifts and accentuating important learning, it is not the only memorization. Brain-Based Learning recommends that educators must submerge students in perplexing, intuitive encounters that are both rich and genuine. Personally, the meaningful challenge can stimulate students' mind to the desired state of alertness that must have by the students (Uzezi \& Jonah, 2017).

One of the important things in learning is comprehending the concept. Students' concept mastery is important that has to be gained by the students. As we know that Physics is one of the difficult subjects for junior high school students (Saleh, 2012). One of the topics in Physics of junior secondary school is an electric circuit. The

Received: 28 September 2018

Revised: 2 January 2019

Published: 9 January2019 
concepts investigated include electric diagrams, current, potential difference at battery terminals, and resistance. It has been repeatedly shown that students and even teachers, make misconceptions. One of these misconceptions is the confusion between potential difference and current (Liégeois, Chasseigne, Papin, \& Mullet, 2003). Evidence suggests that with the right kind of learning environment, Physics can be a valuable learning experience for the majority of students (Redis \& Steinberg, 1999). There are five groups of factors that influence the level of learning achievement other than previous knowledge which has the biggest influence on learning success (Klauer, 1988). These are intellectual capability, environmental components, motivational factors, and the application of learning strategies (Klauer, 1988). One of the efforts to improve students' concept mastery is by using Brain-Based Learning approach. Teachers have to make learning is meaningful for the students because Brain-Based Learning involves accepting the rules of how the brain processes, and then organizing instruction bearing these rules in mind to achieve meaningful learning (Shabatat \& Al-Tarawneh, 2016).

According to Saosa (1995) stated that a Brain-Based approach integrates the engagement of emotions, nutrition, enriched environments, music, movement, meaningmaking and the absence of threat for maximum learner participation and achievement. It is a good strategy to make students' motivate in learning. Brain-Based Learning can be seen as appropriate for school students. Brain-Based Learning will make the students experiencing in the different learning environment as well as the steps is a good strategy to apply in school.

Research on Brain-Based Learning has been conducted in the past two decades (Haghighi, 2013). A previous study by Saleh (2012) it has been found and proven that BrainBased Learning was effective in encouraging conceptual understanding towards physics among students. In another study, Brain-Based Learning was measured achievement of the female students in Chemistry subject (Shabatat \& AlTarawneh, 2016); students' attitudes level and motivation in science class (Akyürek \& Afacan, 2013); students' academic achievement and retention of knowledge in science course (Ozden \& Gultekin, 2013); students' academic achievement, attitude, motivation and knowledge retention in electrochemistry (Uzezi \& Jonah, 2017); and academic achievement of students with different learning styles (Duman, 2010).

Therefore, this study has investigated the difference between students' concept mastery in both control class and experimental class in learning physics, especially for electric circuit topic. There are three teaching materials about the electric circuit, which are the circuit component, series circuit, and parallel circuit. The aim of this study is to investigate the effect of Brain-Based Learning on students' concept mastery in learning the electric circuit.
Table 1 Experiment design

\begin{tabular}{llll}
\hline Control Class & Pre-test & $\begin{array}{l}\text { Lectured- } \\
\text { based Learning }\end{array}$ & Post-test \\
\hline $\begin{array}{l}\text { Experimental } \\
\text { Class }\end{array}$ & Pre-test & $\begin{array}{l}\text { Brain- } \\
\text { based Learning }\end{array}$ & Post-test \\
\hline
\end{tabular}

Table 2 Data of the sample

\begin{tabular}{llllll}
\hline Group & $\begin{array}{l}\text { Popul } \\
\text { ation }\end{array}$ & Sample & N & $\begin{array}{l}\text { Percent } \\
\text { age (\%) }\end{array}$ & $\begin{array}{l}\text { Total } \\
\mathbf{( \% )}\end{array}$ \\
\hline Control & $8^{\text {th }}$ & Male & 13 & 56.52 & 100 \\
& grade & Female & 10 & 43.48 & \\
Experiment & $8^{\text {th }}$ & Male & 15 & 57.70 & 100 \\
& grade & Female & 11 & 42.30 & \\
\hline
\end{tabular}

\section{METHOD}

The research method which was used in this study is quasi-experiment. Quasi-experiments include assignment, but not a random assignment of participants to groups (Creswell, 2012). The experiment design is shown in Table 1.

The location of this research was held in one of International secondary school in Bandung, West Java, Indonesia. The school used the Cambridge curriculum. The population in this research was 8th-grade students. The samples are 8th-grade students from two different classes in international secondary school in Bandung. Students in both groups come from similar educational and socio-economic backgrounds. Their ages ranged between 13-14 years old. The sampling technique was Cluster Random in Class. Fraenkel, Wallen, \& Hyun (2012) stated that cluster random sampling is defined where one is obtained by using groups as the sampling unit rather than individuals. The data of the sample can be seen in Table 2 .

In this study, the topic of the electric circuit is limited based on IGCSE Physics syllabus for secondary students. The subtopics that investigated are (1) Circuit component, (2) Series circuit, (3) Parallel circuit. The experimental group was given Brain-Based Learning. According to Saosa (1995), there are seven steps to conduct Brain-Based Learning which are activation means to activate the students prior knowledge, clarification means clarify the objective and students have their personal performance target, making the connection means they connect their previous understanding with the new information, doing the learning activity means the students are digesting, thinking about, and experiencing multisensory, demonstration of student understanding means the students are in brain active-processing, review of student recall and retention means the students strengthen the transfer process and summarize the knowledge or information, and previewing the new topic means the students are prepared for the new topic. While the control group followed the Lectured-Based Learning that includes lecturing and discussion.

Students' concept mastery from both groups was measured before and after the intervention to determine 
the effectiveness of the implemented Brain-Based Learning. The research was done in five meetings. The first meeting was for pre-test, the second meeting was for circuit component subtopic, the third meeting was for series and parallel subtopic, the fourth meeting was for practical action, and the fifth meeting was for post-test. Students' concept mastery was measured using an objective test of 20 multiple choice questions which consists the cognitive level C1 (remembering), C2 (understanding), C3 (applying), and C4 (analyzing) based on Bloom Taxonomy (Anderson and Krathwohl, 2001). All of the test items were analyzed in the process of judgment from the expert and tested to the students. The result of the test items after the process of judgment will be used, revised, or either deleted. The objective test analyzed using ANATES. The reliability score is 0.78 which is high reliability.

\section{RESULT AND DISCUSSION}

The results show quantitative data. The pre-test and the post-test are conducted to determine the students' concept mastery before and after treatment.

\subsection{Implementation of Brain-Based Learning}

The research was done in five meetings. The first meeting and last meeting was fore pretest and posttest. In this research, experiment class was treated learn with BrainBased Learning, while the control class was treated learned with lectured based learning. The research was done in one of International Junior High School in Bandung in April 2018 with the samples students from 8th-grade in two classes. The instructional process was done in three meetings with the duration in each meeting was 70 minutes. Both the control group and experiment group have the same duration. The pretest was held on April 11th, 2018 and posttest was held on April 25th, 2018. The implementation of Brain-Based Learning was investigated by observation sheet during the lesson. The percentage of Brain-Based Learning implementation is presented in Table 3.

According to Table 3 above about the percentage of Brain-Based Learning implementation, teacher and students implemented or done all activities that have been determined in the lesson plan. The average implementation percentage is $100 \%$ which according to Arikunto (2013) is categorized as very good. The result of Table 3 will be elaborated in the following explanation.

\section{First Treatment}

The first treatment was held on April 12th, 2018 in control group while in the experiment group was held on April 13th, 2018. Both groups learned circuit component subtopic. The main difference as general from both group shown in Table 4

At first, the teacher relates the previous topic about current and the topic that they would learn which was about circuit component by showing them a picture of an
Table 3 Percentage of Brain-Based Learning implementation

\begin{tabular}{clll}
\hline Meeting & Topic & $\begin{array}{l}\text { Percentage of } \\
\text { Implementation }\end{array}$ & Criteria \\
\hline 1 & Circuit & $100 \%$ & All activities \\
& Component & & implemented \\
2 & Series Circuit & $100 \%$ & \\
3 & Parallel Circuit & $100 \%$ & \\
\hline
\end{tabular}

Table 4 Student activities in the first treatment

\begin{tabular}{lll}
\hline Class & \multicolumn{2}{l}{ Description of Activities } \\
\hline Experiment & Start & $\begin{array}{l}\text { Students are shown mind map about } \\
\text { circuit component and did brain gym. }\end{array}$ \\
& Main & $\begin{array}{l}\text { Students did discussion and exercise in } \\
\text { the group when the music is played. } \\
\text { Teacher review the lesson and give the } \\
\text { reward. }\end{array}$ \\
Control & Start & $\begin{array}{l}\text { Students are shown learning objectives } \\
\text { of learning circuit component. }\end{array}$ \\
& Main & $\begin{array}{l}\text { Students did discussion and exercise in } \\
\text { group. } \\
\text { Teacher review the lesson. }\end{array}$ \\
& Close & \\
\hline
\end{tabular}

electric circuit including circuit component. The teacher stated the learning objectives of the lesson and showed the mind map to the students so that the students can develop new knowledge and the teacher gave instruction to do brain gym. All students were joined.

The main activity began, the teacher showed the picture of the circuit component as shown in powerpoint and the students have to predict. They also discussed how the lamp can be turned on/off. The students were given the worksheet and they work with their partner. They had to discuss the difference of closed circuit and open circuit and predict the function of a circuit component in the worksheet. After that, the students discussed in their Kagan's group (a group that has arranged by the school). There was six groups. One of the group was asked to presents the results of discussion and teacher clarified the answer and gave then question example.

The next activity was demonstrating understanding, the students played the game. Each group would have one card. In the card, there are questions about draw the electrical circuit based on the circuit component provided in the questions. All the students were excited because the reward was offered to the group that has the best score. While they were doing their mission, the teacher sets the time so it would be more challenging and classical music was played.

The next activity, the students swap their answer to another student. The answer is shown on the board, the representative of the students wrote it on the board and teacher clarify the answer using colorful board marker. In the end, the teacher reviews the activity and the lesson by asking some questions to the students. Rewards were given to the group that has the best score. There are three groups 
Table 5 Student activities in second treatment

\begin{tabular}{lll}
\hline Class & Description of Activities \\
\hline Experiment & Start & $\begin{array}{l}\text { Students are shown mind map about } \\
\text { series and parallel circuit and do brain } \\
\text { gym. }\end{array}$ \\
Main & $\begin{array}{l}\text { Students did discussion and exercise in } \\
\text { the group when the music is played. } \\
\text { Teacher review the lesson and give the } \\
\text { reward. }\end{array}$ \\
& Start & $\begin{array}{l}\text { Students are shown learning objectives } \\
\text { about series and parallel circuit. } \\
\text { Students did discussion and exercise in } \\
\text { group. } \\
\text { Teacher review the lesson. }\end{array}$ \\
\hline
\end{tabular}

that have the same score. The teacher asked students to prepare the next lesson about series and parallel circuit.

\section{Second Treatment}

The second treatment was held on April 18th, 2018 in both control group and experiment group. Both groups learned series and parallel circuit subtopic. The main difference as general from both group shown in Table 5 .

At first, the teacher relates the previous topic about circuit component and the topic that they would learn which was about series and parallel circuit by showing them a picture of series an parallel circuit. The teacher stated the learning objectives of the lesson and showed the mind map to the students so that the students can develop new knowledge and the teacher gave instruction to do brain gym. All students were joined.

The main activity was begun, the teacher showed the picture of series and parallel circuit as shown in powerpoint and the students have to predict what is the difference between both circuits. One of the students shared the answer. The students were given the worksheet and they work with their partner. They had to discuss the difference of voltage, current, and resistance in series and parallel circuit in their worksheet with a partner. After that, the students discussed in their Kagan's group (a group that has arranged by the school). There was six groups. One of the group was asked to presents the results of discussion and teacher clarified the answer and gave them question example.

The next activity was demonstrating understanding, the students played the game. Each group would have one card. In the card, there are questions about identifying series and parallel circuit. The questions relate also about current, voltage, and resistance. All the students were excited because the reward was offered to the group that has the best score. While they were doing their mission, the teacher sets the time so it would be more challenging and classical music was played. Some of the group looked hard to answer the question and need more time but in the end, they can do the question.

The next activity, the students swap their answer to another student. The answer is shown on the board, the
Table 6 Student activities in third treatment

\begin{tabular}{lll}
\hline Class & Description of Activities \\
\hline Experiment & Start & $\begin{array}{l}\text { Students are shown mind map about the } \\
\text { practical activity and do brain gym }\end{array}$ \\
& Main $\begin{array}{l}\text { Students did discussion and exercise in } \\
\text { the group when the music is played. }\end{array}$ \\
& Close $\begin{array}{l}\text { Teacher review the lesson and give the } \\
\text { reward. }\end{array}$ \\
Control & Start & Students are shown learning objectives \\
& Main & $\begin{array}{l}\text { Students did discussion and exercise in } \\
\text { group. }\end{array}$ \\
& Close & Teacher review the lesson. \\
\hline
\end{tabular}

representative of the students wrote it on the board and teacher clarify the answer using colorful board marker. In the end, the teacher reviews the activity and the lesson by asking some questions to the students and conclude the lesson. Rewards were given to the group that has the best score. There are two groups that have the same score. The teacher asked students to prepare the next lesson about the practical activity of series and parallel circuit.

\section{Third Treatment}

The third treatment was held on April 19th, 2018 in control group while in the experiment group was held on April 20th, 2018. Both groups did the practical activity of series and parallel circuit. The main difference as general from both group shown in Table 6

At first, the teacher relates the previous topic about series and a parallel circuit including some formula and the topic that they would learn which was about the practical activity of series and parallel circuit by showing them some tools of the activity. The teacher stated the learning objectives of the lesson and showed the mind map to the students so that the students can develop new knowledge and the teacher gave instruction to do brain gym. All students were joined but some of them looked more enthusiastic to do the activity.

The main activity began, the teacher showed the PhET (Physics Education Technology) simulation to the students and they have to predict which circuit would have greater current and greater resistance, and also vice versa. They were shown PhET simulation so that they can predict the result of the activity that they would do. One of the students shared the answer. The students were given the worksheet and they work with their group. All of the group make the series and parallel circuit based on the question on the worksheet. The students discussed in the group about the results of ammeter reading, voltmeter reading, and the rheostat affecting the current. One of the group was asked to presents the results of discussion and teacher clarified the answer and gave them question example related to current, voltage, and resistance.

The next activity was demonstrating understanding, the students played the game. Each group would have one card. In the card, there are questions about identifying and 


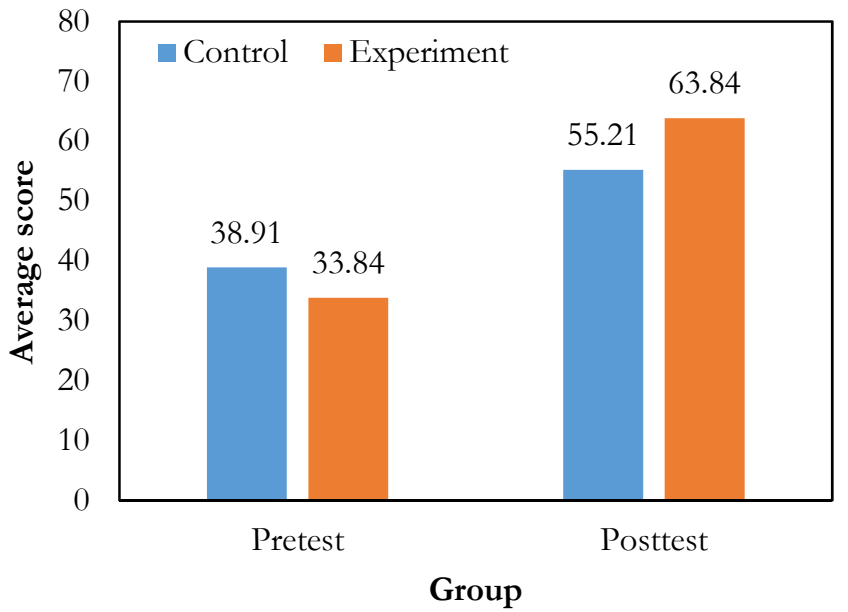

Figure 1 Average score in experiment and control group

calculating the voltage, current, resistance in series and a parallel circuit (lamp and resistor). All the students were excited because the reward was offered to the group that has the best score. While they were doing their mission, the teacher sets the time so it would be more challenging and classical music was played. It is not too conducive since some of the students were playing with the tools, the teacher keeps remind the students not to play with the tools.

The next activity, the students swap their answer to another group. The answer is shown on the board, the representative of the students wrote it on the board and teacher clarify the answer using colorful board marker. In the end, the teacher reviews the activity and the lesson by asking some questions to the students and conclude the lesson. Rewards were given to the group that has the best score. There are two groups that have the same score. The

Table 7 Recapitulation of hypothesis test on students' concept mastery

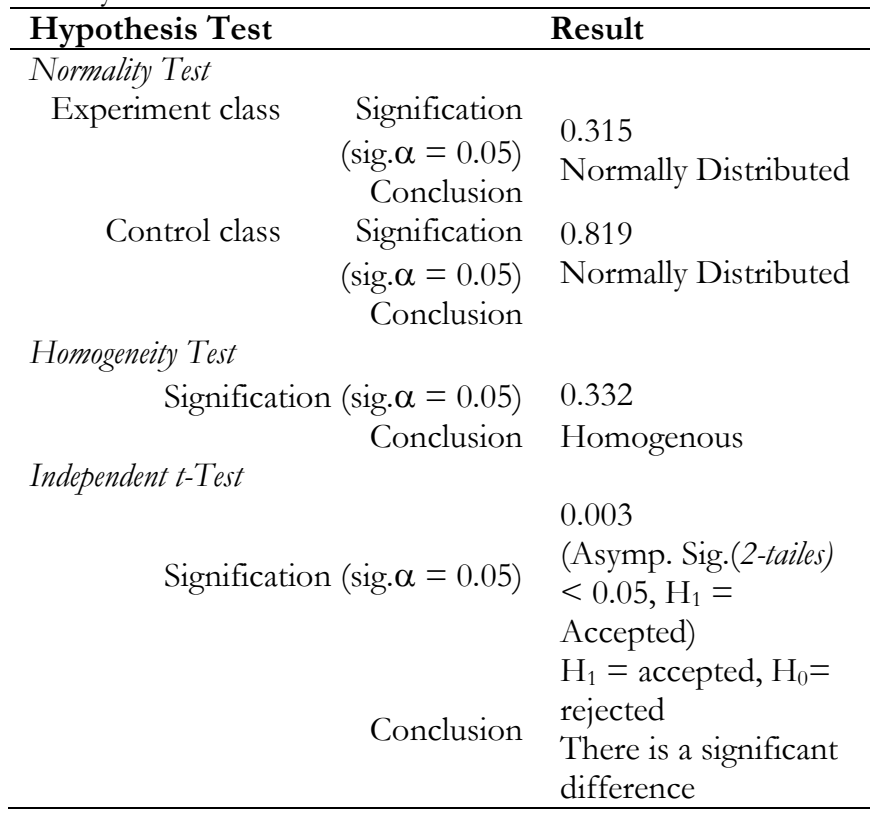

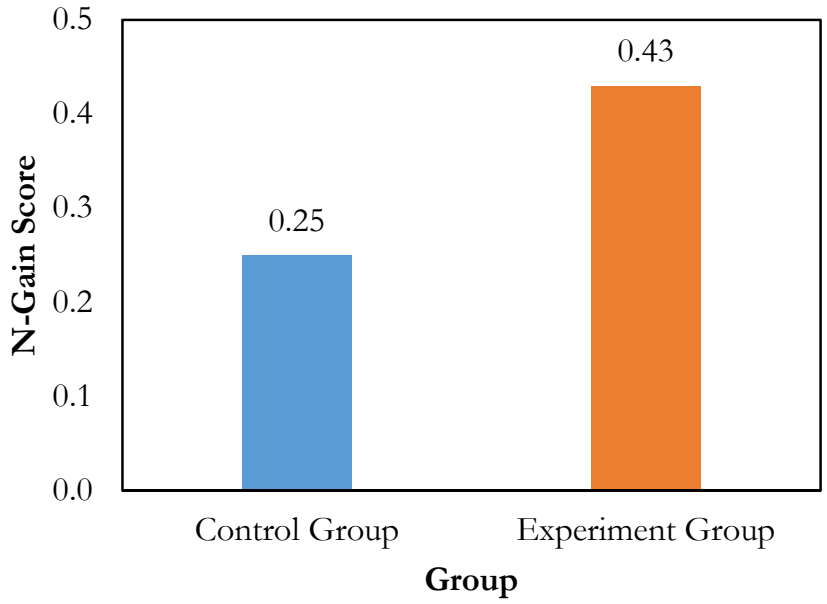

Figure 2 N-Gain score in experiment and control

teacher asked students to prepare the next meeting which is posttest.

\subsection{Students' Concept Mastery}

The results of pretest and posttest score were calculated and the data were analyzed using SPSS version 20 to know whether the data is normally distributed or not. Then, the data is analyzed using a parametric or nonparametric test based on the result of the normality test. The statistic test was done in order to know the difference of concept mastery between control and experiment group. The recapitulation of the statistical test result of control and experiment group is shown in Table 7.

From the results in the Shapiro-Wilk test, the significance value $(\alpha)$ on the control group is 0.819 and 0.315 for experiment group. If compared with the value of $\alpha$ result in sig. $>\alpha=5 \%$ then $\mathrm{H}_{0}$ is accepted which means that the data on the control group and experiment group are normally distributed. Then, continue to homogeneity test. Based on the results of Levene Statistics test, the result of the homogeneity test is 0.332 so if compared with $\alpha$, resulting in $0.332>\alpha=5 \%$, then the data are homogeneous. Since the data is normally distributed and homogenous, then continue with a parametric test which is Independent-Samples T-Test.

The level of significant value used in the test is 0.05 . The results of the test show that the significant value is 0.003 or less than 0.05 , it means that there is the difference in students' concept mastery in learning electric circuit after using Brain-Based Learning (BBL) or there is a significant effect. The average score of students' concept mastery in pretest and posttest is shown in Figure 1.

Based on Figure 1 it can be found that the average of pretest score in the control group was 38.91 and for the experiment, the group was 33.84 . While the average of posttest score in control and experiment group was 55.21 and 63.84. It means there is an improvement on students' concept mastery in learning electric circuit after the treatment. It can be concluded that students from the 
Table 8 Pretest and posttest for each cognitive domain

\begin{tabular}{llllll}
\hline Group & Aspect & \multicolumn{4}{c}{ Cognitive level score } \\
\cline { 3 - 6 } & & C1 & C2 & C3 & C4 \\
\hline Experiment & Pretest & 69.23 & 34.61 & 30.77 & 27.88 \\
& Posttest & 80.76 & 53.84 & 65.38 & 83.65 \\
& G & 11.53 & 19.23 & 34.61 & 55.76 \\
& $<$ g> & 0.12 & 0.22 & 0.45 & 0.75 \\
Control & Category & Low & Low & Medium & High \\
& Pretest & 52.17 & 36.95 & 41.73 & 34.78 \\
& Posttest & 95.65 & 50.43 & 54.78 & 55.43 \\
& G & 43.47 & 13.47 & 13.04 & 20.65 \\
& $<$ g> & 0.43 & 0.18 & 0.06 & 0.29 \\
& Category & Medium & Low & Low & Low \\
\hline
\end{tabular}

experiment group that learned using Brain-Based Learning have a difference in improvement of learning outcomes than the control group in learning the electric circuit. The difference between N-Gain for experiment group and the control group can be seen in Figure 2.

The analysis of N-Gain on control group and experiment group shows that the treatment gives the impact on the improvement of students' concept mastery in learning the electric circuit. The N-Gain score from control group is 0.25 which is categorized as a low improvement while the experiment group got 0.43 which is categorized as a medium improvement (Hake, 1999).

\subsection{Students' Cognitive Domain}

Data continued analyzed from the average of N-Gain from C1, C2, C3, and C4 in both groups. To know the improvement of students understanding in each level, test of N-Gain was done by first grouping the questions based on its cognitive level. Then, find the average of pretest and posttest score, and after that calculating the N-Gain from the control group and experiment group. The results of pretest and posttest for each cognitive dimension in each group is shown in Table 8.

From Table 8 , it can be seen that each cognitive domain shows different results of students' concept mastery either in pretest and posttest. In the control group shows that the average N-Gain on remembering (C1) is 0.43 which is categorized as a medium. The average of $\mathrm{N}$-Gain on understanding $(\mathrm{C} 2)$ is 0.18 which is categorized as low. The average of N-Gain on applying (C3) is 0.06 which is categorized as low, and the average of $\mathrm{N}$-Gain on analyzing (C4) is 0.29 which is categorized as low.

The results in the experiment group show that the average N-Gain on remembering (C1) is 0.12 which is categorized as low. The average of $\mathrm{N}$-Gain on understanding (C2) is 0.22 which is categorized as low. The average of N-Gain on applying (C3) is 0.45 which is categorized as a medium, and the average of N-Gain on analyzing (C4) is 0.75 which is categorized as high. It can be concluded from, in the experimental group has higher improvement in the C4 domain while in control group has

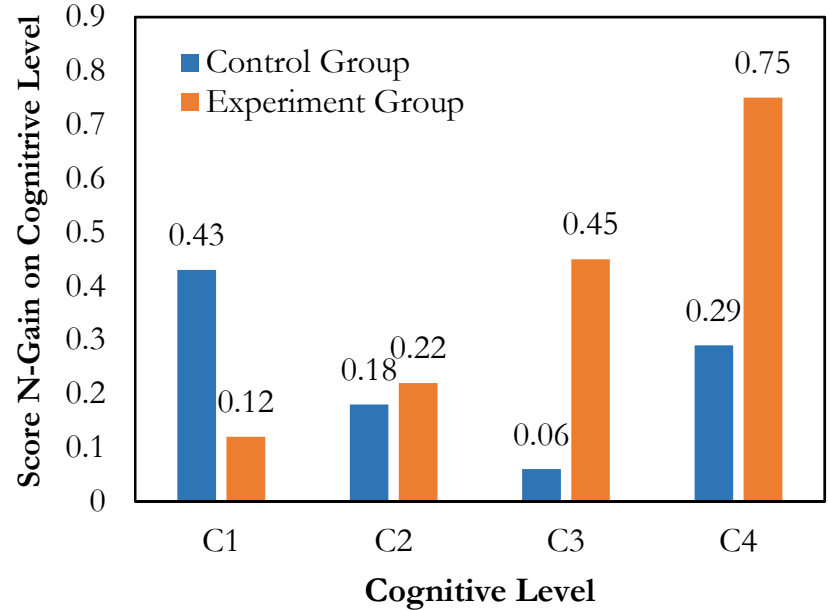

Figure 3 Comparison of the cognitive level of blooms' taxonomy between experiment and control group

higher improvement on $\mathrm{C} 1$ domain. Based on the results, the data can support that the fact that students in the experiment group can more comprehend the topic than in the control group. The improvement for each cognitive level is presented in Figure 3.

According to Figure 4.3, we can see that generally, the experimental group got higher $\mathrm{N}-\mathrm{G}$ ain in cognitive domain C2 (understanding) is 0.22, C3 (applying) is 0.45, and C4 (analyzing) is 0.75. However, for domain C1 (remembering), control group got higher N-Gain because for the control group in the pretest they got a lower score than experiment group. Most of the students in experiment group answered correctly for domain C1 (remembering) in the pretest so that the N-Gain for domain C1 (remembering) is 0.12 which is lower than a control group that got 0.43 .

In C2 (understanding) domain, the experimental group got higher N-Gain than control group although both of them categorized as a low improvement. The low gain was obtained because most of the questions in the test are C2 (understanding) domain. This can be one of the factors because the number of the question if more than other domain.

In C3 (applying) domain, the experiment group got higher N-Gain than the control group. In the question are mostly about the picture of series and a parallel circuit including ammeter and voltmeter. Although both of the group were exercised about this question, in experiment group, they showed PhET simulation and practical activity so that it is easier to understand and more interesting while in control group they only experienced in practical activity.

In C4 (analyzing) domain, experiment group got higher $\mathrm{N}-\mathrm{Gain}$ than the control group. The questions are mostly provided a picture of series and parallel circuit. Only one question requires calculation. The experiment group got higher N-Gain because the students in the class were paying attention compared to the control group. In the control group, not all the students paying attention when 
the teacher explained this type of question. The questions would be easy if they have known the concept.

The cognitive domain result can show that the use of Brain-Based Learning can improve students' ability in all cognitive domain level that was measured. The researchers attributed this result to the benefits of using the BrainBased Learning that was summarized by Caine \& Caine (1997) and Jensen (2012). The strategies harmonized with principles, such as work in groups, encourage cooperation among students, indicate that teaching process will be more efficient when it is conducted within a teaching environment that provides students with chances to exchange experiences within collaboration groups. The use of concept charts which leads to link the major and minor themes together, and organize the knowledge hierarchically makes learners more capable to use, retain the knowledge easily. The note writing (taking notes) help in memorizing the written material. Marshall (2002) and Obeidat and Abussameed (2013) emphasize that taking notes helps knowledge memorization, retrieving, developing, enhancing with more information. Taking notes also make new relations between previous and new knowledge. The use of brainstorming helps in generating creative ideas by encountering a new situation and problem by the students. The review of the previous lesson is important to these strategies whether work in groups, concept charts, notes taking, and brainstorming activates the previous information in the brain. Jensen (2008) discovered that information is not static so it needs frequent review and repetition, else it will be lost or leaked. These skills need more time to apply.

The positive impact is seen by the application of several strategies especially on increasing the interaction of students to the class situations. By applying varied activities and techniques can meet the needs and interests of students and take into account the individual differences, it also helps more relaxation, active processing and improves achievement (Aljorani, 2008).

Another difference between experiment group and control group is brain gym. Brain Gym facilitates the process of waking up the mind/body system, and learning readiness. Through simple integrative movements that focus on specific sensory aspects, Brain Gym activates the full mind/body function across the body midline (Klinek \& Indiana, 2009)

The improving of students' concept mastery that has been found is in line with the research done by Saleh (2012) which found that Brain-Based Teaching Approach was more effective in developing students' conceptual understanding as compared to the conventional method. It is also in line with other research by Shabatat \& AlTarawneh (2016) which found the level of achievement has been improved by using Brain-Based Learning.

Furthermore, the students who learned with BrainBased Learning tend more active in class especially when they had to discuss in a group. They were encouraged with a challenging environment and rewards. This is in line with the finding from Shabatat \& Al-Tarawneh (2016) that based on the results, the researchers found the benefits of using Brain-Based method and principles which are the students work in groups, encourage cooperation among students, environmental support that provides students with chances to exchange experience within collaboration groups. This result in line with a previous study (Ozden \& Gultekin, 2013) that Brain-Based Learning approach appears to be more effective than the traditional teaching procedures in science courses in terms of improving students' academic achievement.

Another difference between experiment group and control group was the utilization of mind map. The experiment group was shown mind map at the beginning of the lesson, it is helpful to improve the achievement of students. This result in line with finding from Jbeili (2013) that using digital mind maps had a significant effect on students' science achievement. The implementation of inquiry activities in experiment group also in line with finding from Wardani (2017) that inquiry-based laboratory activity can improve students' understanding.

\section{CONCLUSION}

Brain-Based Learning can improve students' concept mastery on electric circuit topic. It can be proved by the acceptance of $\mathrm{H}_{1}$ and the result of significance is 0.003 which means that there is a significant difference in learning using Brain-Based Learning on students' concept mastery. The improvement also supported by the results of $\mathrm{N}$-Gain in experiment group is 0.43 which is categorized as medium improvement and N-Gain in control group is 0.25 which is categorized as a low improvement. It can be concluded also that Brain-Based Learning improved students' concept mastery in all cognitive level. BrainBased Learning can be one of the alternative teaching approaches that can improve students' concept mastery in learning the electric circuit.

\section{ACKNOWLEDGMENT}

Author's wishing to acknowledge the principal of the school for the permission to conduct the research (teaching in the class for several meetings).

\section{REFERENCES}

Akyürek, E., \& Afacan, Ö. (2013). Effects of Brain-Based Learning Approach on Students' Motivation and Attitudes Levels in Science Class. Mevlana International Journal of Education, 3(1), 104-119.

Al-Tarawneh, M. (2016). The Impact of a Teaching-Learning Program Based on a Brain-Based Learning on the Achievement of the Female Students of 9th Grade in Chemistry. Higher Education Studies, 6(2), 162.

Aljorani, Y. (2008). Teaching design according to brain-based learning and its impact on the achievement of 9th-grade students in biology and development of their scientific thinking. Baghdad, Iraq: University of Baghdad. 
Anderson, L. W., \& Krathwohl, D. R. (Eds.). (2001). A Taxonomy for Learning, Teaching, and Assessing. New York: Addison Wesley Longman, Inc.

Arikunto, S. (2013). Dasar-Dasar Evaluasi Pendidikan. Jakarta: Bumi Aksara.

Assalti, N. (2004). Brain-based learning (1st ed.). Amman, Jordan.

Caine, R., \& Caine, G. (1997). Making Connection: Teacbing and Brain. Alexandria, VA: ASCD.

Creswell, J. W. (2012). Educational Research Fourth Edition. Boston: Pearson.

Duman, B. (2010). The Effects of Brain-Based Learning on the Academic Achievement of Students with Different Learning Styles. Educational Sciences: Theory \& Practice Educational Sciences: Theory \& Practice, 10(4), 2077-2103.

Fraenkel, J. E., Wallen, N. E., \& Hyun, H. H. (2012). How To Design and Evaluate Research In Education. New York: Mc Graw Hill.

Haghighi, M. (2013). The effect of brain-based learning on Iranian EFL achievement and retention. Procedia - Social and Behavioral Sciences, 70, 508-516.

Hake, R. R. (1999). Analyzing Change/ Gain Score. Retrieved from http://www.physics.indiana.edu

Jbeili, I. M. A. (2013). The Impact of Digital Mind Maps on Science Achievement among Sixth Grade Students in Saudi Arabia. Procedia - Social and Behavioral Sciences, 103, 1078-1087.

Jensen, E. (2008). Brain-Based Learning (Second). California: Corwin Press.

Jensen, E. (2012). Teaching with the brain in mind, workshop held. USA, San Antonio. Retrieved from http://www.jennsenlearning.com/pdf/10mosteffectiveTips.pdf

Klauer, K. J. (1988). Teaching for learning-to-learn: a critical appraisal with some proposals. Instructional Science, 17(4), 351-367.

Klinek, S. R., \& Indiana. (2009). Brain-based Learning: Knowledge, Beliefs, and Practices of College of Education Faculty in The Pennsylvania State System of Higher Education. Vasa, (May), 1$188 . \quad$ Retrieved from http://medcontent.metapress.com/index/A65RM03P4874243N. pdf
Liégeois, L., Chasseigne, G., Papin, S., \& Mullet, E. (2003). Improving high school students' understanding of potential difference in simple electric circuits. International Journal of Science Education, 25(9), 1129-1145.

Marshall, B. (2002). The secrets of getting better grades: Study smarter not harder (2nd edition). Park Avenue: JIST Publishing, Inc.

Obeidat, T., \& Abussameed, S. (2013). Brain function-based Learning. Retrieved from http://www.anawatifly.blasspo

Ozden, \& Gultekin. (2013). The Effects of Brain-Based Learning on Academic Achievement and Retention of Knowledge in Science Course. Electronic Journal of Science Education, 12(1), 1-17.

Redis, E. F., \& Steinberg, R. N. (1999). Teaching Physics: Figuring Out What Works. Physics Today, 52. Retrieved from https://www.physics.umd.edu/perg/qm/qmcourse/NewModel/ research/whatwork/index.htm

Saleh, S. (2012a). The Effectiveness of Brain-Based Teaching Approach in Dealing with The Problems of Students' Conceptual Understanding and Learning Motivation towards Physics. Educational Studies, 38(1), 19-29.

Saleh, S. (2012b). The Effectiveness of the Brain-Based Teaching Approach in Enhancing Scientific Understanding of Newtonian Physics among Form Four Students. International Journal of Environmental and Science Education, 7(1), 107-122.

Shabatat, K., \& Al-Tarawneh, M. (2016). The Impact of a TeachingLearning Program Based on a Brain-Based Learning on the Achievement of the Female Students of 9th Grade in Chemistry. Higher Education Studies, 6(2), 162.

Sousa, D. 1995. How the brain learns. A classroom teacher's guide. Reston, VA: National Association of Secondary School Principals.

Uzezi, J. G., \& Jonah, K. J. (2017). Effectiveness of Brain-based Learning Strategy on Students 'Academic Achievement, Attitude, Motivation and Knowledge Retention in Electrochemistry. Journal of Education, Society and Behavioural Science, 21(3), 1-13. https://doi.org/10.9734/JESBS/2017/34266

Wardani, T. B., \& Winarno, N. (2017). Using Inquiry-based Laboratory Activities in Lights and Optics Topic to Improve Students' Understanding About Nature of Science (NOS). Journal of Science Learning, 1(1), 28-35. 